\title{
The Model of Heavy Industries Profitability
}

(Case Study at Astra International - Indonesian)

\author{
R. Nasution ${ }^{1}$, Danny Ramdani ${ }^{* 2}$ \\ Economic and Business Faculty of Singaperbangsa Karawang University-Indonesia \\ nasution@fe.unsika.ac.id, \\ Economic and Business Faculty of Singaperbangsa Karawang University- Indonesia \\ danny.ramdani@feb.unsika.ac.id \\ Correspondence Author
}

Article History: Received: 11 January 2021; Accepted: 27 February 2021; Published online: 5 April 2021

\begin{abstract}
The purpose of this study was to analyze the influence of cash turnover, receivebles turnover and sales on profitability of Astra International registered on Indonesian Stock Exchange within the time span of eight years (2011 to 2018). Methods of data analysis using the classic assumption test, multiple linear regression analysis, F test, and t test. The Finding of this study were cash turnover, receivable turnover,and sales have a simultaneously affect on profitability of Firm, Whereas the two variables, cash turnover and sales had a partially positive affect on profitability of Firm, Meanwhile receivable turnover had a partially negative affect on profitability of Firm. The implication of this study to the firm in facing challenging business conditions is to implement cost efficiency programs that emphasize various innovative steps and at the same time focus on the availability of distribution support, ease of access and guaranteed product and service quality for customers.
\end{abstract}

Keywords : Cash Turnover, Receivable Turnover, Sales and Profitability

\section{INTRODUCTION}

In the world of business, every firm will encounter a stringent competition each other to make customers interesting in its products offered. The management will be running a business strategy in each of their activities to prevail over competation to achieve a goal as target plan, so that the firm could sustain its business competive advantage. It means, the firm will keep its profit on upcoming. Profitability is very important for the development of the firm because with it of all activities, and operations can run well.

The industry is one of the primary absorbers of manufacturing jobs in Indonesia, alongside the electronics, garments, footwear, and textile industries. Among the automotive subsectors, the component industry has the highest number of employees.

Indonesia ranks ninth in the world in terms of manufacturing industry competitiveness. Indonesia's manufacturing industry ranked 18th in 1990, ranked 15th in 2000, 14th in 2010, 11th in 2015, and ranked 9th in 2016. Judging from the percentage of manufacturing industry to GDP, Indonesia far left other ASEAN countries not even entered in the top 15. This ranking is the result of a recent survey conducted by the United Nations Industrial Development Organization (UNIDO) at the end of 2016.

According to data from the Association of Indonesia Automotive Industries (GAIKINDO, 2016), the automotive industry is an important economic sector for Indonesia, contributing more than US\$.5 billion worth of exports in 2015. In 2016, Indonesia exported 194,397 completely built-up vehicles and 202,626 completely knocked-down units, alongside 6,233,114 components, in what has been an upward trend since 2012. Despite a slight drop in export performance in 2016, the automotive sector remains among the leading export sectors for Indonesia, its growth rate continuing a more positive trend compared to most other commodities, particularly in the weakening trade environment.

Astra International was established in 1957 in Jakarta as general trading. By 2018, the firm had expanded its business by implementing a business model based on synergies and diversification within seven business segments, consisting of:1) Automotive, 2) Financial Services, 3) Heavy Equipment, Mining, Construction and Energy, 4) Agribusiness, 5) Infrastructure and Logistics, 6) Information Technology and 7) Property.

The automotive segment is the cornerstone of firm, which unceasingly delivers exceptional achievements. Beginning as distributor for Toyota in 1969, this segment developed and today is able to offer a wide range of choices as well as the latest models of vehicles that cater to consumers' needs. From Honda motorcycles to cars of various types, Toyota, Daihatsu and Isuzu trucks, to BMW, Peugeot and UD Trucks. Through its extensive distribution and service network, the largest in Indonesia, Firm ensures consumers convenience when purchasing or maintaining their vehicles. Firm's financing companies, which offer both conventional and syariah credit schemes, and firm Otoparts, which produces a wide variety of spare parts and accessories, also support this 
segment. With its commitment to quality products and aftersales services, Astra International stands at the forefront of Indonesia's automotive industry market. In operation activities of the firm, capital has a huge role to sustain viabilty of it,such as :to purchase raw material, to pay wage and short term-debt. The company issued working capital is expected to re-enter the financial account with a short period of production sales so that working capital continues to spin in the company every period, Riyanto, (2014). According to Haq et al. (2011), such decisions directly influence organizational profitability.

Cash and receivable have an important effect on profit og firm, so, it needs an effective and efficiency handling. Riyanto (2014) said that: Cash turnover is the ratio between sales with average cash amount. The higher the cash turnover rate means the faster the cash return goes to the company.. Cash turnover illustrates the ability of cash in generating income so that it can be seen how many times the cash revolves in a certain period. Higher cash turnover rates the sooner the return of cash into the company. Receivables turnover is a comparison between credit sales and average receivables. Receivables turnover shows an attempt to measure how often receivables become cash in a period. Higher the accounts receivable turnover, the faster the return of cash to the company.

Based on financial reporting of Astra International that cash turnover of firm within the time span of 2011 to 2018 had experienced a fluctuation, the greatest was 10,85 times, and the smallest was 1,03 times. Meanwhile the highest receivable turnover was 7,42 times, and the smallest was 1,41 times. Whereas the highest sales result was 144.810 billion, and the smallest was 22.475 billion. .And the highest profit of firm was 23.165 billion, and the smallest was 15.613 billion.

Based on the background described above, the authors are interested in choosing the object of research on Astra International companies listed on the Indonesia Stock Exchange (IDX). The authors are interested in conducting research entitled: “ Analysis of Factors The Influencing on Profitability of Heavy Industries".

The present study would address the following questions:

\lrcorner Does cash turnover have an effect on company Profitability?

\lrcorner Does receivable turnover have an effect on company Profitability?

\lrcorner Does sales have an effect on company Profitability?

\lrcorner Do cash turnover, receivable turnover, and sales have an effect on company Profitability?

\section{EMPIRICAL REVIEW}

In this study, the main concern of author is to find out the impact of cash turnover, receivable turnover and sales on profitability of the Astra International. Many researchers discussed in their research papers different reprensent of the working capital management,as :

Gorondutse, at.el (2017) analyzed the effect of working capital management on Small Enterprises profitability in Malaysia. They established a positive effect of cash conversion cycle on net operating profit. In addition, the study showed a positive effect of day's accounts payable on the overall returns of Small Enterprises from net operating profit. The study concluded that the profitability of Small Enterprises in Malaysia depended on how effective they manage their working capital.

DDK Sugathadasa (2018) The Relationship between Cash Conversion Cycle and Firm Profitability: Special Reference to Manufacturing Companies in Colombo Stock Exchange, there is a significant relationship between cash conversion cycle and firm's profitability in manufacturing sector in Sri Lanka by implying that there is a severe need to address on working capital requirement issues appropriately.

Kyalo (2011) observed that working capital management is a critical instrument of success for any business. According to the study, prudent management of the working capital management enhances strategic competitiveness by increasing firm's profitability. In addition, the efficient management of the working capital will enhance growth of the firm's market share, industry lifecycle and its progress in production.

Yanti (2018) observed a research at Food and Beverages company listed on the Indonesia Stock Exchange for period years of 2011 to 2015 . The results showed that the cash turnover, receivable turnover, and inventory turnover have a simultaneously affect on profitability of Food and Beverages company.

Muhammad Aqil (2019) performed a research on Heavy Vehicle Industry in Pakistan. The results revealed that most of the elements of working capital have a significant effect on return on equity and return on assets.

Muhammad, at.el (2012) based on 25 textile companies which traded in Pakistan's Karachi Stock Exchange between 2001-2006 stated that there is a positive relation between profitability and accounts receivable and a negative relation between profitability and liabilities. Additionally, the raises in cash, inventories and receivables increase the profitability of the companies.

Therefore, effective working capital management could increase the profitability.

Titik Purwanti (2019) conducted a research at all manufacturing companies listed on the Indonesia Stock Exchange for period years of 2011 to 2015. The results of the analysis of this study are the cashturnover and accounts receivable simultaneously affect profitability. Partially, the two variables also affect profitability.

Haryanto (2018) studied at Indofood Sukses Makmur Company listed on the Indonesia Stock Exchange for period years of 2010 to 2017. The results showed that the cash turnover, receivable turnover, and inventory turnover simultaneously affect on Return on Assets (ROA). 
Mburu (2010) also conducted a study on the relationship between working capital management and profitability among the insurance companies. He succinctly found a strong relationship between working capital management and profitability of the insurance firms.

Agha, Mba, and Mhil (2014), investigated the impact of WC management on profitability. Theauthors used data collected from Glaxo Smith Kline listed pharmaceutical company in Karachi Stock Exchange for the year 1996- 2011. Return on assets ratio had been used for the measurement of profitability, while accounts receivable turnover, creditors turnover, inventory turnover, and current ratio for the measurement of working capital. The study found that the WC significantly affects firm's profitability, and profitability can be enhanced through minimizing inventory turnover, accounts receivable ratio, and through reducing creditors' turnover ratio. In addition, the study found that no significant effect of current ratio on the profitability of firms.

Mihajloy (2014), carried out a study regarding the impact of accounts receivable on profitability during financial crisis. The study investigates how listed firms in at the regular market of Serbia manage their accounts receivable. The author used the most successful 108 firms listed in the Prime and Standards Listing and in Multilateral Trading Platform of the Belgrade Stock Exchange, and the accounts receivables had been tested in the study during the financial crisis of 2008-2011. The study found that between accounts receivable and two dependent variables including return on total assets and operating profit margin, there was an insignificant positive relationship, which means that during financial crisis, the impact of receivables on profitability is changing.

Manyo and Ike (2013), carried out a study to investigate whether return on assets is affected byaccounts receivables. The authors claim that WC plays an important role in the performance of selected Nigerian firms over the period 2000-2009. Data analysis and hypotheses testing revealed the existence of a significant negative relationship between accounts receivables and return on assets. This conclusion means that profitability increases as average collection period of receivables from customer's decreases. This is because collected amounts can be reinvested somewhere in the firm.

Muscettola, (2014), investigated the importance of cash conversion cycle on firm's profitability. The author's aim of the study was to verify the impact of all components of cash conversion cycle on profitability of Italian firms. The sample of the study consisted of 4,226 Italian manufacturing firms. The study takes Earnings Before Interest, Tax, Depreciation, and Amortization (EBITDA) on net sales as a good measure of profitability. Results of the study showed that average receivables period has a significant positive association with profitability of firms. Moreover, the study showed that it is not necessary that lesser cash conversion cycle means greater profitability to measure the dependent variable of the study.

Nthiwa, at.el (2013) conducted a study on management of working capital and its effect on profitability of the Manufacturing companies listed on NSE, Kenya. They found an insignificant relationship between profitability and inventory turnover.

Januaris (2015) conducted a study on the effect of working capital management on profitability of public listed energy companies in Kenya. He found that short cash conversion cycle was more profitable and had significant effect on profitability.

Several research studies have demonstrated that there is an inverse influence of receivable turnover on the profitability (Bhatia \& Srivastava, 2016, Sharma \& Kumar, 2011).

\section{RESEARCH METHOLOGY}

\section{Sampel and Data}

This research uses descriptive methods. The populations of this study are all financial reporting of Astra International listed on the Indonesia Stock Exchange. The sample used can represent the condition of public company in Indonesia which are listed on the Indonesian Stock Exchange. Based on the predetermined criteria the author has obtained a samples used, namely Cash Turnover, Receivable Turnover and Sales on Profitability of Company for period years of 2011 to 2018.

\section{Method of Analysis}

Methods of data analysis used are the classic assumption test, multiple linear regression analysis, F test, and $t$ test.

\section{RESULT AND DISCUSSION}

\section{Result}

Based on quarters financial reporting of company during 2011 till 2018, the following recapitulation result of analysing and processing data, included as : cash turnover, Receivable Turnover, sales and Net Profit Margin as shown at tabel.1. 
Tabel.1 Cash Turnover, Receivable Turnover, Sales and Net Profit Margin Astra International Years of 2011 to 2018

\begin{tabular}{|c|c|c|c|c|c|}
\hline Years & Quarter & $\begin{array}{c}\text { Cash } \\
\text { Turnover }\end{array}$ & $\begin{array}{l}\text { Receivable } \\
\text { Turnover }\end{array}$ & Sales & $\begin{array}{c}\text { Net Profit } \\
\text { Margin }\end{array}$ \\
\hline 2011 & Quarter 1 & 2,94 & 2,35 & 22.475 & $\begin{array}{c}5.07 \\
0 \\
\end{array}$ \\
\hline & Quarter 2 & 3,97 & 4,07 & 47.098 & 10.084 \\
\hline & Quarter 3 & 5,37 & 5,64 & 72.175 & 15.922 \\
\hline & Quarter 4 & 7,88 & 7,42 & 98.956 & 21.077 \\
\hline \multirow{4}{*}{2012} & Quarter 1 & 2,28 & 1,99 & 30.341 & 5.464 \\
\hline & Quarter 2 & 4,68 & 3,72 & 58.358 & 11.369 \\
\hline & Quarter 3 & 7,40 & 5,21 & 91.036 & 17.198 \\
\hline & Quarter 4 & 10.85 & 7,31 & 123.520 & 22.742 \\
\hline \multirow{4}{*}{2013} & Quarter 1 & 2,70 & 1,81 & 35.737 & 4.946 \\
\hline & Quarter 2 & 4,62 & 3,45 & 73.257 & 10.129 \\
\hline & Quarter 3 & 5,76 & 4,89 & 107.754 & 15.386 \\
\hline & Quarter 4 & 7,12 & 6,52 & 139.845 & 22.297 \\
\hline \multirow{4}{*}{2014} & Quarter 1 & 1,79 & 1,65 & 34.482 & 5.710 \\
\hline & Quarter 2 & 3,84 & 3,07 & 69.345 & 11.821 \\
\hline & Quarter 3 & 5,30 & 4,35 & 103.181 & 17.468 \\
\hline & Quarter 4 & 6,55 & 6,13 & 140.608 & 22.125 \\
\hline \multirow{4}{*}{2015} & Quarter 1 & 1,31 & 1,50 & 36.067 & 4.808 \\
\hline & Quarter 2 & 2,89 & 3,15 & 73.518 & 9.758 \\
\hline & Quarter 3 & 3,97 & 4,46 & 107.190 & 14.611 \\
\hline & Quarter 4 & 4,66 & 6,49 & 143.332 & 15.613 \\
\hline \multirow{4}{*}{2016} & Quarter 1 & 1.03 & 1,54 & 31.558 & 3.639 \\
\hline & Quarter 2 & 2,11 & 3,14 & 64.389 & 8.310 \\
\hline & Quarter 3 & 3,09 & 4,60 & 94.610 & 13.231 \\
\hline & Quarter 4 & 4,32 & 6,34 & 126.381 & 18.302 \\
\hline \multirow{4}{*}{2017} & Quarter 1 & 1,09 & 1,59 & 29.587 & 6.083 \\
\hline & Quarter 2 & 2,11 & 3,00 & 62.867 & 11.357 \\
\hline & Quarter 3 & 3,25 & 4,21 & 93.806 & 17.421 \\
\hline & Quarter 4 & 4,59 & 5,47 & 128.705 & 23.165 \\
\hline \multirow{4}{*}{2018} & Quarter 1 & 1,16 & 1,41 & 35.078 & 6.334 \\
\hline & Quarter 2 & 2,65 & 2,60 & 69.770 & 13.194 \\
\hline & Quarter 3 & 3,51 & 3,78 & 105.885 & 21.517 \\
\hline & Quarter 4 & 5,50 & 5,10 & 144.810 & 27.372 \\
\hline
\end{tabular}

Source: Corporate financial report 2011 to 2018 (after processed)

To get to know the effect of variables each of cash turnover (X1), receivable turnover (X2), and sales (X3) on company net profit margin must therefore be conducted with statistic analysis by using a software SPSS 25 .

\section{CLASSICAL ASSUMPTION TEST}

Tabel. 2 Normalitas Test One - Sample Kolmogorov Test

Unstandardized

Residual

\begin{tabular}{|c|c|c|}
\hline \multicolumn{3}{|l|}{$\begin{array}{l}\mathbf{N} \\
32\end{array}$} \\
\hline \multirow{2}{*}{ Normal Parameters a,b } & Mean &, 0000000 \\
\hline & Std.Deviation & 1226,72047770 \\
\hline \multirow{3}{*}{ Most Extreme Differences } & Absolute & , 125 \\
\hline & Positive &, 125 \\
\hline & Negative & .112 \\
\hline \multicolumn{3}{|l|}{$\begin{array}{l}\text { Test Statistic } \\
, 125\end{array}$} \\
\hline $\begin{array}{l}\text { Asymp.Sig.(2-tailed) } \\
\text {,200 c,d }\end{array}$ & & \\
\hline
\end{tabular}


a. Test distribution is Normal

b. Calculated from data

c. Lillifors Significance Correction

d. This is a lower bound of the true significance

Resources : Processing data by SPPS 25

From the Asymp.Sig.(2-tailed) test results showed on table.2 that the significance value of 0,200 is greater than 0.05 . This shows that the regression equation for the model in this study has a normal distribution of data.

Tabel. 3 Multikolinieritas Test Coefficient ${ }^{\mathrm{a}}$

\begin{tabular}{|l|c|c|c|c|c|c|c|}
\hline \multicolumn{1}{|c|}{ Model } & $\begin{array}{c}\text { Unstandardized } \\
\text { B }\end{array}$ & $\begin{array}{c}\text { Coefficient } \\
\text { Std.Error }\end{array}$ & $\begin{array}{c}\text { Std. } \\
\text { Coefficient } \\
\text { Beta }\end{array}$ & T & Sig. & $\begin{array}{c}\text { Collinearity } \\
\text { Tolerance }\end{array}$ & $\begin{array}{c}\text { Statistic } \\
\text { VIF }\end{array}$ \\
\hline 1.(constant) & 136,124 & 566,728 & &, 240 &, 812 & & \\
\hline $\begin{array}{l}\text { Cash } \\
\text { Turnover }\end{array}$ & 692,010 & 213,062 &, 235 & 3,248 &, 003 &, 236 & 4,233 \\
\hline $\begin{array}{l}\text { Receivable } \\
\text { Turnover }\end{array}$ & $-667,622$ & 365,381 &, 183 & $-1,827$ &, 078 &, 122 & 8,165 \\
\hline Sales &, 111 &, 008 &, 967 & 13,741 &, 000 &, 249 & 4,017 \\
\hline
\end{tabular}

a. Dependent Variabel : Net Profit

Resources : Processing data by SPPS 25

Based on table. 3 shows that the Cash Turnover with a VIF value of 4.233 is less than the VIF value of 10 and a tolerance value of 0.236 is greater than the minimum tolerance value of 0.1 then there is no multicollinearity. Receivable Turnover with a VIF value of 8.165 is less than the VIF value of 10 and a tolerance value of 0.122 is greater than the minimum tolerance value of 0.1 so there is no multicollinearity. Sales with a VIF value of 4.017 is less than the VIF value of 10 and a tolerance value of 0.249 is greater than the minimum tolerance value of 0.1 so there is no multicollinearity.

\section{Picture. 1 Heteroskedastisitas Test \\ Dependent Variable : Net Profit Margin}

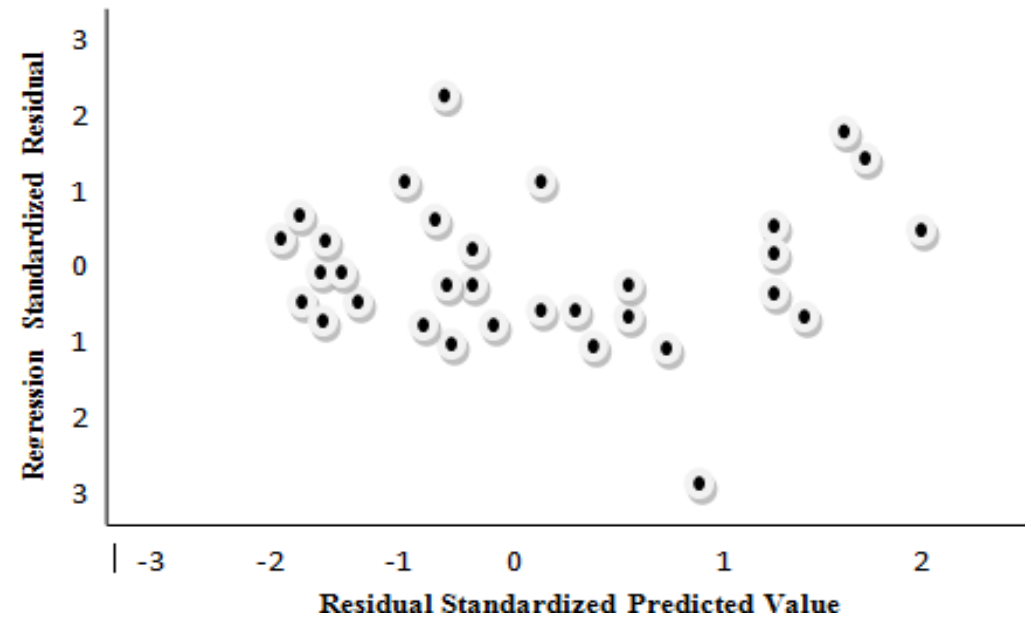

Resources : Processing data by SPPS 25

From scatterplot grafic mentioned on picture. 1 above could be pointed out that spreading of dotties reside in either above or below of zero value Y axis. So, It could be concluded that there is no a heteroskedastisitas at regression model, therefore it is proper or worthy to predict net profit of company.

Tabel.4 Autokorelasi Test Model Summaryb

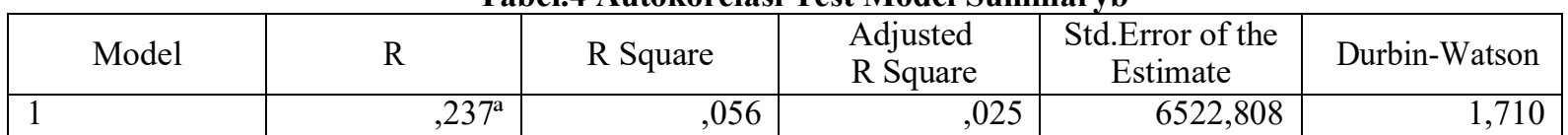

a. Predictors : (Constant), Cash Turnover, Receivable Turnover, Sales

b. Dependent Variabel : Net Profit

Resources : Processing data by SPPS 25 
The Model of Heavy Industries Profitability (Case Study at Astra International - Indonesian)

Based on table. 4 above, using the degree of error $(\alpha)=5 \%$, with sample $(\mathrm{N}) 32$, and three independent variabel (K-3). With refer to the Durbin Watson table will find the upper limit (U) is 1,6505 while the lower limit (L) is equal to 2,2437. Because the DW value of the regression result is 1.710 which means greater than the lower bound value, $(1.6505<1.710<2,2437)$ then the autocorrelation coefficient is greater than zero. Thus it can be

concluded that the regression results are free from the autocorrelation problem. In other words, a hypothesis that states that there is no autocorrelation problem can be accepted, while a null hypothesis that there is an autocorrelation can be rejected.

\section{HYPOTHESIS TESTING}

Table. 5 Multiple Linear Regression Analysis Coefficient ${ }^{\mathbf{a}}$

\begin{tabular}{|l|c|c|c|c|c|c|c|}
\hline \multicolumn{1}{|c|}{ Model } & $\begin{array}{c}\text { Unstandardized } \\
\text { B }\end{array}$ & $\begin{array}{c}\text { Coefficient } \\
\text { Std.Error }\end{array}$ & $\begin{array}{c}\text { Std } \\
\text { Coefficient } \\
\text { Beta }\end{array}$ & T & Sig. & $\begin{array}{c}\text { Collinearity } \\
\text { Tolerance }\end{array}$ & $\begin{array}{c}\text { Statistic } \\
\text { VIF }\end{array}$ \\
\hline 1.(constant) & 136,124 & 566,728 & &, 240 &, 812 & & \\
\hline $\begin{array}{l}\text { Cash } \\
\text { Turnover }\end{array}$ & 692,010 & 213,062 &, 235 & 3,248 &, 003 &, 236 & 4,233 \\
\hline $\begin{array}{l}\text { Receivable } \\
\text { Turnover }\end{array}$ & $-667,622$ & 365,381 &, 183 & $-1,827$ &, 078 &, 122 & 8,165 \\
\hline Sales &, 111 &, 008 &, 967 & 13,741 &, 000 &, 249 & 4,017 \\
\hline
\end{tabular}

a. Dependent Variabel : Net Profit

Resources : Processing data by SPPS 25

Based on result of processing mentioned on tabl.5 above find out an equation of Multiple Linear Regression Analysis,as : Net Profit Margin $(\mathbf{Y})=136,124+692,010(\mathbf{X 1})-667,622(\mathbf{X} 2)+0,111(\mathbf{X 3})+\mathbf{e}$. From the results of the hypothesis test shows the value of the profitability variable constant with a positive parameter is 136,124 . This shows that if the variable cash turnover,receivable turnover and sales are assumed to be zero, then the profitability of companies on the Indonesia Stock Exchange will be 136,124. From the regression equation above shows the regression coefficient of cash turnover with a positive parameter is 692,010. Every increase in cash turnover once will increase profitability by692,010. From the regression equation above shows the receivable turnover regression coefficient with a negative parameter is -667,622. Every increase in receivable turnover 1 time will reduce profitability by 667,622 . From the regression equation above shows the regression coefficient of sales with a positive parameter is 0,111 . Every increase in sales once will increase profitability by 0,111 .

Tabel. 6 T Test Coefficient ${ }^{\mathrm{a}}$

\begin{tabular}{|l|c|c|c|c|c|c|c|}
\hline \multicolumn{1}{|c|}{ Model } & $\begin{array}{c}\text { Unstandardized } \\
\text { B }\end{array}$ & $\begin{array}{c}\text { Coefficient } \\
\text { Std.Error }\end{array}$ & $\begin{array}{c}\text { Std. } \\
\text { Coefficient } \\
\text { Beta }\end{array}$ & T & Sig. & $\begin{array}{c}\text { Collinearity } \\
\text { Tolerance }\end{array}$ & $\begin{array}{c}\text { Statistic } \\
\text { VIF }\end{array}$ \\
\hline 1.(constant) & 136,124 & 566,728 & &, 240 &, 812 & & \\
\hline $\begin{array}{l}\text { Cash } \\
\text { Turnover }\end{array}$ & 692,010 & 213,062 &, 235 & 3,248 &, 003 &, 236 & 4,233 \\
\hline $\begin{array}{l}\text { Receivable } \\
\text { Turnover }\end{array}$ & $-667,622$ & 365,381 &, 183 & $-1,827$ &, 078 &, 122 & 8,165 \\
\hline Sales &, 111 &, 008 &, 967 & 13,741 &, 000 &, 249 & 4,017 \\
\hline
\end{tabular}

b. Dependent Variabel : Net Profit

Resources : Processing data by SPPS 25

From the results of the table. 6 above, we can find out the results of the t test for the variable cash turnover,receivable turnover,and sales towards profitability. From the regression results it is known that the value of the t-count variable cash turnover is 3.248 greater than t table 2,048. With a significance value of 0.003 smaller than $\alpha=0.05$. This shows that the cash turnover variable has a significant effect on profitability. From the regression results it is known that the magnitude of the t-count of receivable turnover variable is -1.827 smaller than t table 2,048, with a significance value is 0.078 bigger than $\alpha=0.05$. This shows that the receivable turnover variable has no a significant effect on profitability. From the regression results it is known that the magnitude of the t-count of sales variable is 13,741 greater than $\mathrm{t}$ table 2,048, with a significance value of 0.000 smaller than $\alpha$ $=0.05$. This shows that the sales variable has a significant effect on profitability.

Tabel.7 F Test ANOVA ${ }^{\mathrm{a}}$

\begin{tabular}{|l|c|c|c|c|c|}
\hline \multicolumn{1}{|c|}{ Model } & Sum of Squares & Df & Mean Square & F & Sig. \\
\hline 1 Regression & 1305714296,679 & 3 & 435238098,892 & 261,235 &, $000 \mathrm{~b}$ \\
\hline Residual & 46650137,043 & 28 & 1666076,232 & & \\
\hline
\end{tabular}




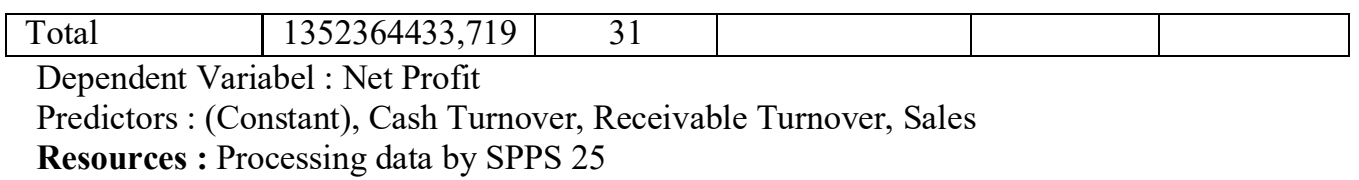

Based on the data generated from the calculation of table.7 obtained F count of 261.235 is greater than $\mathrm{F}$ table 2.92 with 0.000 significance less than the significant value $\alpha=0.05$ so that it can be concluded that simultaneously or together the variable cash turnover, receivable turnover,and sales are factors affecting profitability variables. From the F test results it can be seen that The regression model used in this study shows the goodness of fit model.

Tabel. 8 Determinant Coefficient Model Summaryb

\begin{tabular}{|c|c|c|c|c|c|}
\hline Model & $\mathrm{R}$ & R Square & $\begin{array}{c}\text { Adjusted R } \\
\text { Square }\end{array}$ & $\begin{array}{c}\text { Std.Error } \\
\text { of the } \\
\text { Estimate }\end{array}$ & Durbin.Watson \\
\hline 1 &, $237^{\mathrm{a}}$ & 0,56 & 0,25 & 6522,808 & 1,710 \\
\hline
\end{tabular}

Dependent Variabel : Net Profit

Predictors : (Constant), Cash Turnover, Receivable Turnover, Sales

Resources : Processing data by SPPS 25

The calculation results as mentioned on tabel. 8 for the $\mathrm{R} 2$ value obtained by the coefficient of determination with R Sequare is 0.56 . This means that $56 \%$ of the profitability variable variation can be explained by the variable cash turnover, receivable turnover, and sales while the remaining $44 \%$ is pointed out by other factors outside the model studied

\section{DISCUSSION OF TEST RESULT}

The Effect of Cash Turnover on Profitability.

Regression results are known that the value of the $t$-count variable cash turnover is 3.248 greater than $t$ table 2,048 . with a significance value of 0.003 smaller than $\alpha=0.05$. This shows that the cash turnover variable has a significant effect on profitability. It indicated that the increasing of Astra International cash turnover has a significant effect on profitability for period of reseach. According to Riyanto (2011) The higher of cash turnover rate means the faster the cash return goes to the company. Thus, cash will be reused for operational activities so as not to disrupt the company's financial condition. The company cash turnover have experienced a greater increasing at Quarter 4 in 2012, that was 10,85 times, whereas smaller value of cash turnover was 1,03 times at Quarter 1 in 2016.

This research was reinforced by Titik Purwanti (2019) said that cash turnover has a significant effect on profitability. This is because companies in running their business always need cash. Cash expenditures for a company can be continuous, for example cash expenditures for the purchase of raw materials, payment of salaries and others.

\section{The Effect of Receivable Turnover on Profitability.}

Regression results are known that the value of the t-count variable receivable turnover is -1.827 smaller than $\mathrm{t}$ table 2,048. with a significance value is 0.078 greater than $\alpha=0.05$. This shows that the receivable turnover variable has no a significant effect on profitability. It caused of an overdue payment or a claim from or to customers by Astra International. The company receivable turnover have experienced a higher increasing at Quarter 4 in 2011,that was 7,42 times, whereas lower value of cash turnover was 1,41 times at Quarter 1 in 2018.

This research was reinforced by Rika Ayu Nurafika (2018) said that receivable turnover has no a significant effect on profitability. She told that a certain of higher receivable turnover should be followed up by a quick claim receivable, because receivable is an element of working capital which is also always in a state of continuous rotation in the working capital turnover chain.

\section{The Effect of Sales on Profitability.}

Regression results are known that the value of the t-count variable sales is 13,741 greater than $t$ table 2,048. with a significance value of 0.000 smaller than $\alpha=0.05$. This shows that the sales variable has a significant effect on profitability.It means that sales has a direct role to increase the Astra International profit, and company has 
proved its sales growing since 2011 till 2018, where The sales has experienced a higher increasing at Quarter 4 in 2018, that was 144.810 million, whereas lower value of sales was 29.587 million at Quarter 1 in 2017.

This research was reinforced by Lili Susanti.et,all (2018) said that sales has a significant effect on profitability

\section{The Effect of Cash Turnover, Receivable Turnover, Sales on Profitability}

Regression results are known that the data generated from the calculation obtained $\mathrm{F}$ count is 261.235 greater than F table 2.92 with 0.000 significance less than the significant value $\alpha$ is 0.05 so that it can be concluded that cash turnover, receivable turnover,and sales have a simultaneously affect on profitability of Astra International. Where the coefficient of determination with $\mathrm{R}$ Sequare is 0.56 . This means that $56 \%$ of the profitability variable variation can be explained by the variable cash turnover, receivable turnover, and sales.

\section{CONCLUSION}

Based on the results of research, data analysis and discussion that has been conduced mentioned above, it can be concluded for several things as follows:

Cash turnover has a partially positive and significant effect on profitability, this shows that if cash turnover increases, profitability will also increase, whereas Receivable turnover has a partially negative effect on profitability, this shows that if the receivable turnover was late in claim, company will have a big problem and Sales has a partially positive and significant effect on profitability. All variables, cash turnover, receivable turnover and sales have a Simultaneously positive and significant effect on profitability.

\section{REFERENCES}

\section{BOOKS:}

1. Brealey, Richard A., Stewart C. Myers, dan Franklin Allen. (2011). Principles of Corporate Finance. 10 ed. New York: McGraw-Hill Education

2. Ghozali, Imam.( 2016). “Aplikasi Analisis Multivariete Dengan ProgramIBM SPSS 23 (Edisi 8)”. Cetakan VIII, Semarang : Badan Penerbit Universitas Diponegoro.

3. Hantono, dan Rahmi N.U. (2018). "Pengantar Akuntansi”. Buku 1 Edisil Yogyakarta : Dee Publish. ISBN 978-602-453-837-8.

4. Hery. (2016). “Analisis Laporan Keuangan”. Jakarta : PT Grasindo. ISBN 978-602-375-540-0.

5. Riyanto Bambang. (2014). “Dasar-dasar Pembelanjaan Perusahaan”. Edisi Keempat. BFEEYogyakarta. Yogyakarta.

6. S.R., Soemarsono. (2017). “Akuntansi Suatu Pengantar”. Buku 1 Edisi 5. Jakarta: Salemba Empat. ISBN 979.691-145-0.

7. Sekaran, Uma.2015. “Research Methods For Business”. Edisi Empat Jilid 1. Jakarta: Salemba Empat. ISBN 979-691-317-8.

8. Sugiyono. (2017). "Metode Penelitian Kuantitatif, Kualitataif dan R\&D”. Bandung: Alfabeta.

\section{JOURNAL:}

9. Agha, H., Mba, and Mphil, (2014). "Impact of Working Capital Management on Profitability", European Scientific Journal, 10 (1), 374-381.

10. Bhatia, S., Srivastava, A. (2016), "Working capital management and firm performance in emerging economies: evidence from India”, Management and Labour Studies, Vol. 41, No. 2, pp. 71-87.

11. Haryanto, at.el (2018). "Effect Of Teurnover of Cash, Receivables Turnover and Inventory Turnover on Return on Assets (ROA): Case Study in PT Indofood Sukses Makmur Tbk”. International Journal of Art Humanities and Social Sciences Vol. 3 No. 1.

12. Haq I. U., et.al (2011), "The Relationship between Working Capital Management and Profitability: A Case Study of Cement Industry in Pakistan”, Mediterranean Journal of Social Sciences, Vol. 2, No. 2, pp. 365-372

13. Kyalo (2011) Relationship between working capital management and profitability of cement companies in Kenya (Doctoral dissertation, University of Nairobi).

14. Manyo, T. S., and Ike, U. J., (2013). "The Effect of Accounts Receivable on Return on Assets of Selected Nigerian Firms"; International Journal of Current Research, 5 (12), 3767-3772.

15. Mihajlov, k. D., (2014). "Impact of Accounts Receivable Management on the Profitability During the Financial Crisis: Evidence from Serbia", 9th International ASECU Conference on "Systemic Economic Crisis: Current Issues and Perspectives; University of Nis, Serbia. 
16. Muhammad Aqil at.el (2019) "Factors Influencing the Profitability of Heavy Vehicle Industry: A Case of Pakistan. Montenegrin Journal of Economics, Vol. 15, No. 1 (2019), 061-072

17. Muhammad, Malik.at.el (2012), "Working Capital Management and Profitability an Analysis of Firms of Textile Industry of Pakistan”, Journal of Managerial Sciences, V. 6 N. 2, pp. 155-165.

18. Muscettola, M., (2014). "Cash Conversion Cycle and Firm's Profitability: An Empirical Analysis on A Sample of 4,226 Manufacturing SMEs of Italy), International Journal of Business and Management, 9 (5), 25-35.

19. Nthiwa, at.ell (2013) Management of working capital and its effect on profitability of manufacturing companies listed on Nairobi securities exchange (NSE), Kenya.

20. Rika Ayu Nurafika (2018) "Effect of Cash Turnover,Receivable Turnover, Inventory Turn over on Profitability, study at Cement Manufacture ”. Journal of Accountant and Business Vol. 4 No. 1. ISSN 2243-3071 e-ISSN 2503-0337.

21. Novi Yanti. (2018). "Effect of Cash Turnover,Receivable Turnover, Inventory Turn overon Profitability, study at Food And Baverages Company listed on Indonesia Stock Exchange Tahun 2011-2015”. Journal of Indovisi Vol. 1 No. 1.ISSN 2615-4234 e-ISSN 2615-3254.

22. Sharma, A.K., Kumar, S. (2011), "Effect of working capital management on firm profitability empirical evidence from India”, Global Business Review, Vol. 12, No. 1, pp. 159-173

23. Titik Purwanti (2019) "An Analysis of Cash and Receivables Turnover Effect Towards Company Profitability. International Journal of Seocology (Science, Education, Economics, Psychology and Technology). 